\title{
Greenfield Investments and Acquisitions of Turkish Multinationals: Trends, Motivations and Strategies
}

\author{
Caner Bakir ${ }^{\mathrm{a}}$ and Nuran Acur ${ }^{\mathrm{1}}$

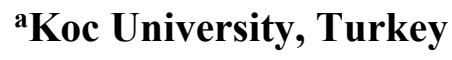 \\ ${ }^{b}$ University of Strathclyde, UK \& Ozyegin University, Turkey
}

\section{Introduction}

Recently, Foreign Direct Investment (FDI) in Europe from emerging markets reached a record high in 2013 (Ernst and Young 2014: 6). Indeed, Emerging Market Multinationals (EMNCs) have started to play an increasingly important role in the economic globalisation processes (UNCTAD 2006). Unsurprisingly, explaining the rather sudden rise of EMNC investments in developed markets has become a major concern among policy makers and scholars over the last few years (Ramamurti and Singh 2009; Ramaurti 2009a,b; CuervoCazurra and Ramamaurti 2014; Brennan 2011; Goldstein 2007; Khanna and Palepu 2006).

Internationalisation of Turkish Multinational Corporations (TMNCs) is part of this economic globalisation process. According to UNCTAD (2015: 52), TMNC outward investments reached 6.7 billion US dollars in 2014, or increased by $89 \%$ compared to the previous year. In 10 years, from 2004 to 2013, TMNC greenfield investments increased over threefold from 2.2 billion US dollars to 6.9 billion US dollars (fDi intelligence database).

During the same period, the top 62 TMNC acquisitions, whose value exceeded 10 million US dollars, increased over 17 times from 108 million US dollars to 1.8 billion US dollars (Thomson Reuters Mergers and Acquisitions database and Deloitte Turkish Outbound

\footnotetext{
${ }^{1}$ Bakir gratefully acknowledges the support of The Scientific \& Technological Research Council of Turkey (TÜBİTAK, 110K346 and Postdoctoral Fellowship for Research Abroad, TÜBİTAK 2219). This paper is also related to COST Action IS0905 The Emergence of Southern Multinationals and their Impact on Europe. Authors also thank Pinar Donmez, Mustafa Yagci, and Mina Kozluca for their assistance.

This is an accepted Author Manuscript of the following book chapter: Bakir, C., \& Acur, N. (2016). Greenfield investments and acquisitions of Turkish multinationals: trends, motivations and strategies. In L. Brennan, \& C. Bakir (Eds.), Emerging Market Multinationals in Europe. (pp. 129-156). London: Routledge.
} 
$M \& A$ Review 2012-2013). More significantly, over 95\% of these investments are new investments rather than an expansion of existing investments. Thus, it is legitimate to investigate this new spectacular increase in TMNC investment activities. Further, several Turkish firms have internationalised in aggressive and innovative ways, whilst competing with established players. Some of the non-financial TMNCs are now among the world's global players in several industries, ranging from food (Yildiz Holding) to ferrocrome (Yildirim Group), to tiles (Eczacibasi Yapi).

One area that has not received much attention in the past literature on EMNCs, however, is the recent geographical and sectoral spread, motivations, and competitive advantages of TMNCs; whether these investments represent theoretical and empirical challenges to existing knowledge, or whether they can be explained within the existing theoretical frameworks that have been used to explain developed country MNCs (see Bakir 2016).

This chapter offers answers to questions such as: Where do TMNCs go? What are their Firm Specific Advantages (FSAs) and Country Specific Advantages (CSAs)? Why do they internationalise? Are widely used frameworks in international business (IB) theory relevant to explain TMNC behaviour? Are some of the largest TMNC acquisitions in EU motivated by the global consolidator strategy? How do structural complementarities inform the outcome of TMNC acquisitions?

This chapter finds that the largest TMNCs employ multiple strategies in developed and developing country markets. $75 \%$ of TMNC greenfield FDI (or about 35 billion US dollars) is directed towards transition and developing economies. TMNCs mainly exploit FSAs (dynamic capabilities) obtained at home, such as managerial and market knowledge, expertise, technology, local/regional brands and distribution channels, and expertise in operating in relatively weak institutional environments in these economies. They also exploit traditional locational advantages, or CSAs, such as economies of scale and leadership in home market, 
geographical, cultural and institutional proximity. In contrast to greenfield investments, $50 \%$ of their acquisitions (or 4.9 billion US dollars) are in developed countries, where they not only exploit current FSAs obtained from home CSAs, but also aim to explore FSAs obtained from host CSAs through their subsidiaries. In regards to motivations, TMNCs' greenfield investments are mainly motivated by market-seeking FDI, including access to host country markets and neighbouring regions, efficiency-seeking FDI such as cost and tax advantages, and resource-seeking FDI such as access to natural resources.

TMNCs' acquisitions are mostly motivated by strategic asset-seeking FDI such as access to global brands, international experience, knowledge, distribution networks, and cutting-edge competitive technology. In doing so, they aim to increase their market share and profitability at home and abroad. This chapter also highlights the global consolidator strategy of some TMNCs and the significance of structural complementarities arising from the structural context informing TMNC investment behaviour.

Data for this chapter come from the Financial Times Ltd fDi Intelligence (2003-2013) and Thomson Reuters Mergers and Acquisitions Database (from 1 January 2000 to 30 January 2011) and Deloitte Turkish Outbound M\&A Review 2012-2013. It also benefits from secondary written sources. Acquisitions data focuses on transactions over 10 million US dollars by TMNCs where at least $51 \%$ of ownership belongs to a Turkish owner.

The rest of this chapter is organised as follows. Section two offers a literature review. Section three focuses on greenfield investment trends by TMNCs with special reference to economic development of host countries, regional, country-based, and sectoral distribution of the value of these investments. Section four does the same for outbound acquisitions. Section five discusses the internationalisation strategies and motivations of some of the largest TMNCs, and the role of structural complementarities in informing TMNC internationalisation strategy. The conclusion summarizes the main findings. 


\section{Literature Review}

Research and practice regarding the internationalisation of firms have been dominated by the Eclectic paradigm (Dunning 1988), and FSAs and CSAs frameworks (Rugman and Verbeke 1990). The Eclectic paradigm is based on Ownership, Location, and Internalisation advantages (OLI framework). Ownership advantages such as technology, knowhow, and brand, indicate who is going to produce abroad "and for that matter, other forms of international activity" (Dunning, 1993: 142). These advantages are also labelled as FSAs. Locational factors refers to home country resource endowments, such as natural resources, labour, market size, and institutions that "influenc[e] where to produce" (Dunning, 1993: 143). These advantages are also known as CSAs that "can be based on natural resource endowments (minerals, energy, forests), market, labour force, and/or associated cultural factors" (Rugman 2009: 50). Internalisation advantage "addresses the question of why firms engage in FDI rather than license foreign firms to use their proprietary assets" (Dunning, 1993: 145). Here, ownership advantages are exploited internally where such advantages are not sold to third parties through contracts such as licensing and the establishment of joint ventures (i.e., MNCs do not sell their FSAs to their rivals). OLI advantages are regarded as the necessary and sufficient conditions for the internationalisation of MNCs (Hennart 2012: 169). It is widely held that developed country multinationals mostly rely on the exploitation of their FSAs, such as technology, knowhow, and brand, whilst developing country MNCs do not have strong FSAs, and they rely heavily on CSAs, such as cheap labour, natural resources, and access to state funds (Rugman 2009). It is widely recognised that MNCs from developing countries have home CSAs, such as cheap and skilled labour, scale advantages arising from strong demand in growing domestic markets (Luo and Tung 2007), and they enjoy monopolistic power in home markets (Klein and Wocke 2007). Several studies argued that EMNCs internationalise to gain FSAs in host 
countries, rather than exploiting their existing FSAs obtained in home countries (Mathews 2002; Luo and Tung 2007; Ramamurti and Sigh 2009; Williamson et.al. 2013).

Recently, it has been argued that EMNCs have several FSAs obtained in home markets, which are different than standard FSAs or ownership advantages of developed country MNCs. As Ramamurti (2012: 42) rightly notes:

Among the ownership advantages attributed in the literature to EMNEs is their deep understanding of customer needs in emerging markets, the ability to function in difficult business environments, their ability to make products and services at ultra-low costs, their ability to develop "good enough" products with the right feature-price mix for local customers, and so on.

Some of the EMNCs are "global consolidators," who are the leaders in their home markets and consolidate the industry globally by acquiring firms in developed countries (Ramamurti and Sigh 2009). For example, in his analysis of Indian MNCs, Ramamurti (2013: 251) identifies "the global consolidator strategy [that] typically arises in industries that have matured in developed countries but are booming in emerging markets - industries like cement, steel, chemicals, white goods, automobiles, beverages and processed foods". These firms use the mix of FSA exploitation and FSA exploration for efficiency. Further, Ramamurti and Sigh (2009: 141-142) note that

\footnotetext{
The distinguishing feature of the global consolidator ....is that its competitive advantages can be leveraged in both emerging economies and advanced countries, resulting in the potential for up-market exports and FDI...[this is because] industry-specific factors - specifically, in the degree to which products and production processes [that] can be standardized across countries, regardless of per-capita income, wages, or cultural differences.
}

Has there been any TMNC that adopted the global consolidator strategy? This chapter also aims to address this question with special reference to Yildiz Holding, the largest food manufacturer and marketer in Turkey, which acquired top global brands such as the Belgium chocolate maker, Godiva Chocolatier in 2007, and the top manufacturer and marketer of biscuits in the UK, United Biscuits in 2014.

Past research has also shown that MNCs have four main motivations in internationalisation (Dunning 1993; Narula and Dunning 2010). These are: 1) natural resource- 
seeking to access host country resources; 2) market-seeking to access host country markets and regions, to overcome trade-related and other restrictions, as well as to become closer to customers; 3) efficiency-seeking to decrease costs and reconfigure supply chains; and 4) strategic asset-seeking to acquire intangible assets such as knowhow and brand. The first three motivations relate to the exploitation of FSAs obtained from home country CSAs, whilst the last one relates to the exploration of FSAs obtained from host country CSAs.

More recently, for Rugman and Nguyen (2014: 56-57), “[n]ew internationalization theory maintains that FSAs can be developed by both parent firms in the home countries and foreign subsidiaries in the host countries. ... What is missing from all the extant literature on EMNCs is the interaction between foreign subsidiaries of EMNCs and the host CSAs." Accordingly this chapter considers FSAs obtained from both home and host CSAs.

More significantly, this chapter highlights some of the weaknesses in the IB theory, namely the significance of the largely ignored structural context that informs investment decisions and entry strategies of MNCs. It shows that structural complementarities (i.e., interdependence of structural influences on MNC behaviour) reinforce FSAs and/or CSAs generating similar incentives that influence the internationalisation outcomes of MNCs (for a detailed discussion on the structural complementarities in the context of bank behaviour, see Bakir 2013; for the role of institutional complementarities on actor behaviour, see Campbell 2011 and Crouch 2010). In this context, the sociology and political economy literature may offer new analytical insights highlighting the utility of introducing structural variables. In doing so, we can further understand the timing and context of internationalisation of MNCs. Following Sewell (1992:19) structures "are sets of mutually sustaining schemas and resources that empower and constrain social action and that tend to be reproduced by that social action". Here, structures refer to broader material and ideational contexts within which institutions (i.e., formal and informal rules and norms that guide the behaviour of agents) and agents (e.g., 
individuals and organisations) are embedded. Structures, like institutions, inform the internationalisation of MNCs. The examples include crises, wars, technical and technological innovations, macroeconomic structures, market structures, currency structures, ideational structures etc., that guide the behaviour of corporations

This nuanced view is important because it moves beyond conventional FSA and CSA based analysis of firms' internationalisation activities. For example, although MNCs' internationalisation activity is informed by FSAs and CSAs, the realisation of investment may require the existence of structural complementarities that reinforce a firm's motivations and strategies (If one wishes to race ahead, I summarise this point in section five below). These complementarities may create structural-level enabling conditions for outward investment.

There are four main contributions of this chapter to these discussions on EMNCs. First, there is an empirical gap in the past EMNC literature which ignored internationalisation of TMNCs. This literature mostly focuses on MNCs from Brazil, Russia, India and China (here after BRIC) (see for example, Ramamurti and Singh 2009; Guillén and García-Canal 2012; Cuervo-Cazurra ve Ramamaurti 2014; Demirbağ and Yaprak, 2015). Second, it shows that TMNCs have ownership advantages or FSAs which are different than developed country MNCs. This finding is largely ignored in the previous research on TMNCs and some of the IB perspectives on EMNCs which have focused on CSAs. Third, it also argues that "modern international business theory [that has been developed to analyse Western MNCs], with its distinctions between FSAs generated by home or host country recombinations" (Rugman and Nguyen 2014: 76), is highly relevant in explaining some of the TMNC investments. In addition to exploiting standard FSAs obtained from Turkey's CSAs, such as economies of scale, and low labour cost, TMNCs also explore ownership advantages and strategic assets (also known as dynamic capabilities or FSAs) obtained from foreign MNCs and markets. Finally, it offers 
examples of influence of largely ignored structural complementarities in informing the outcomes of EMNCs' internationalisation strategy.

This chapter also makes three main contributions to the previous literature on TMNCs and outward Turkish FDI (see, for example, Akçaoğlu 2005; Erdilek 2003, 2007; Kaya and Erden 2008; Kaya 2009). First, although TMNC internationalisation activities have exploded over the last 10 years, our knowledge of outward TMNC investments is limited. Earlier studies have mainly focused on the 1990s when EMNCs were relatively opaque in the global business environment and the literature on EMNCs was underdeveloped. Second, the current study pays special attention to the TMNC investments in advanced developed regions and countries, in particular the European Union (EU), with special reference to some of the cutting edge discussions in the newly emerging EMNC literature. Third, one of the unique contributions of this chapter to the literature on TMNCs is its reliance on the analysis of private databases. The previous studies have used publicly available aggregated data supplied by the Central Bank of the Republic of Turkey, United Nations Conference on Trade and Development (UNCTAD) or newspapers (bkz. Akçaoğlu 2005; Kayam and Hisarcıklılar 2009). The current chapter instead uses private databases and firm-specific data which focus on the last decade rather than the 1990s. Thus this chapter offers discussions about individual TMNC advantages and motivations in their recent integration with the economic globalisation process.

\section{Greenfield Investments by Turkish MNCs}

Table 9.1: Greenfield investments of non-financial TMNCs (2003-2013) 


\begin{tabular}{lcccccc}
\hline Number of & $\begin{array}{c}\text { Number of } \\
\text { Investor } \\
\text { Companies }\end{array}$ & $\begin{array}{c}\text { Total } \\
\text { Investment } \\
\text { Value (million } \\
\text { US dollars) }\end{array}$ & $\begin{array}{c}\text { Average Value } \\
\text { of Capital } \\
\text { Investment by } \\
\text { Companies } \\
\text { (million US } \\
\text { dellars) }\end{array}$ & $\begin{array}{c}\text { Total } \\
\text { Employment } \\
\text { Created }\end{array}$ & $\begin{array}{c}\text { Average } \\
\text { Employment } \\
\text { Created by } \\
\text { Companies }\end{array}$ \\
\hline 2003 & 109 & 58 & 7,750 & 133.6 & 30,574 & 527 \\
2004 & 66 & 48 & 2,374 & 49.5 & 10,450 & 218 \\
2005 & 67 & 41 & 4,074 & 99.4 & 25,836 & 630 \\
2006 & 51 & 37 & 1,941 & 52.5 & 14,520 & 392 \\
2007 & 37 & 33 & 2,399 & 72.7 & 15,346 & 465 \\
2008 & 64 & 52 & 4,464 & 85.8 & 16,649 & 320 \\
2009 & 63 & 59 & 4,068 & 68.9 & 20,811 & 353 \\
2010 & 100 & 67 & 3,852 & 57.5 & 21,689 & 324 \\
2011 & 66 & 50 & 4,911 & 98.2 & 6,699 & 134 \\
2012 & 86 & 59 & 4,155 & 70.4 & 12,797 & 217 \\
2013 & 83 & 65 & 6,864 & 105.6 & 20,643 & 318 \\
Total & 792 & 438 & 46,852 & 81.28 & 196,014 & 354 \\
\hline
\end{tabular}

Source: $f D i$ Intelligence from the Financial Times Ltd. Author's calculations.

Note:* Includes real sector firms and financial firms.

** Share of foreign MNCs operating in Turkey in total is negligible.

Table 9.1 presents data for greenfield activities of TMNCs, such as building factories and opening branches or stores between January 2003 and December 2013. During this period, 438 TMNCs invested over 46 billion US dollars in 792 investments. Over 95\% of TMNCs are family-owned firms rather than state-owned firms. These investments created employment opportunities for over 196 thousand people. On average, each TMNC invested 82 million US dollars and employed 354 people. 2003 witnessed a record in total capital investment with 7.7 billion US dollars. This could be connected to the postponed investments due to the 2001 economic and financial crisis in Turkey. The second highest investment was realised in 2013. In 2009 and 2010, when the repercussions of the global financial crisis were felt, outward investment declined around 10\% compared to 2008 .

\subsection{Regional Distribution of Investment Flows}

Figure 9.1 shows the distribution of the value of TMNC investments among host countries according to their level of economic development. Transition economies (21.4 billion US dollars or $46 \%$ of the total) and developing countries (13.7 billion US dollars or $29 \%$ ) 
received the highest value of investments. Compared to these economies, investments to developed economies are higher in number, yet lower in value (10.6 billion US dollar or 22\%).

Figure 9.1: Distribution of non-financial TMNC Investments by A Host Country's Economic Development (2003-2013, Value of Investments - Million USD)

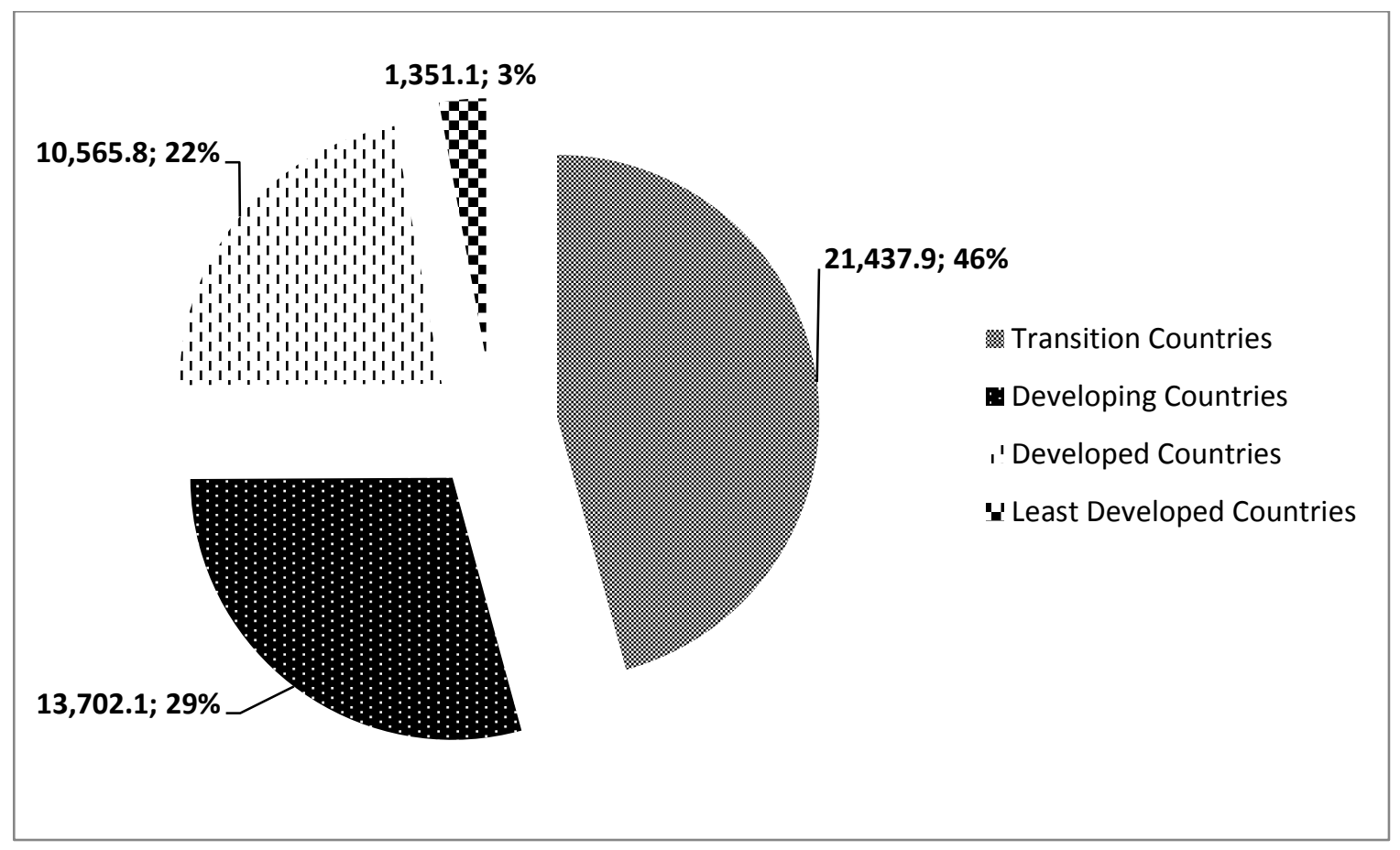

Source: fDi Intelligence from the Financial Times Ltd. Author's calculations.

What does the fact that around $75 \%$ of TMNC greenfield FDI is directed towards transition and developing economies mean? TMNCs use the competitive advantages in areas such as costs, management, marketing, logistics, and technology that they gained to reach new markets in developing and transition economies (see section 5). In contrast, the total value of investments by Turkish companies in developed country economies is about $20 \%$ of the total. This may be due to these firms' weak FSAs in these markets. In contrast, the emerging interest of TMNCs in the least developed countries suggests that the share of LDCs ( $3 \%$ at present) might increase in time. 


\subsection{Geographical Distribution of Greenfield FDI}

Figure 9.2 shows the geographical distribution of TMNC greenfield investments by value. The Commonwealth of Independent States (CIS) received the highest investments with 18.5 billion US dollars or $39 \%$ of the total investments. The second most attractive location for greenfield investments by TMNCs is the EU, which attract $18 \%$ of the total investments. 318 investments have been made in this region by 217 TMNCs and over 41 thousand people were employed by the investment worth 8 billion US dollars.

Figure 9.2: Geographical Distribution of non-financial TMNC Investments (2003-2013, Value of Investments - Million USD)

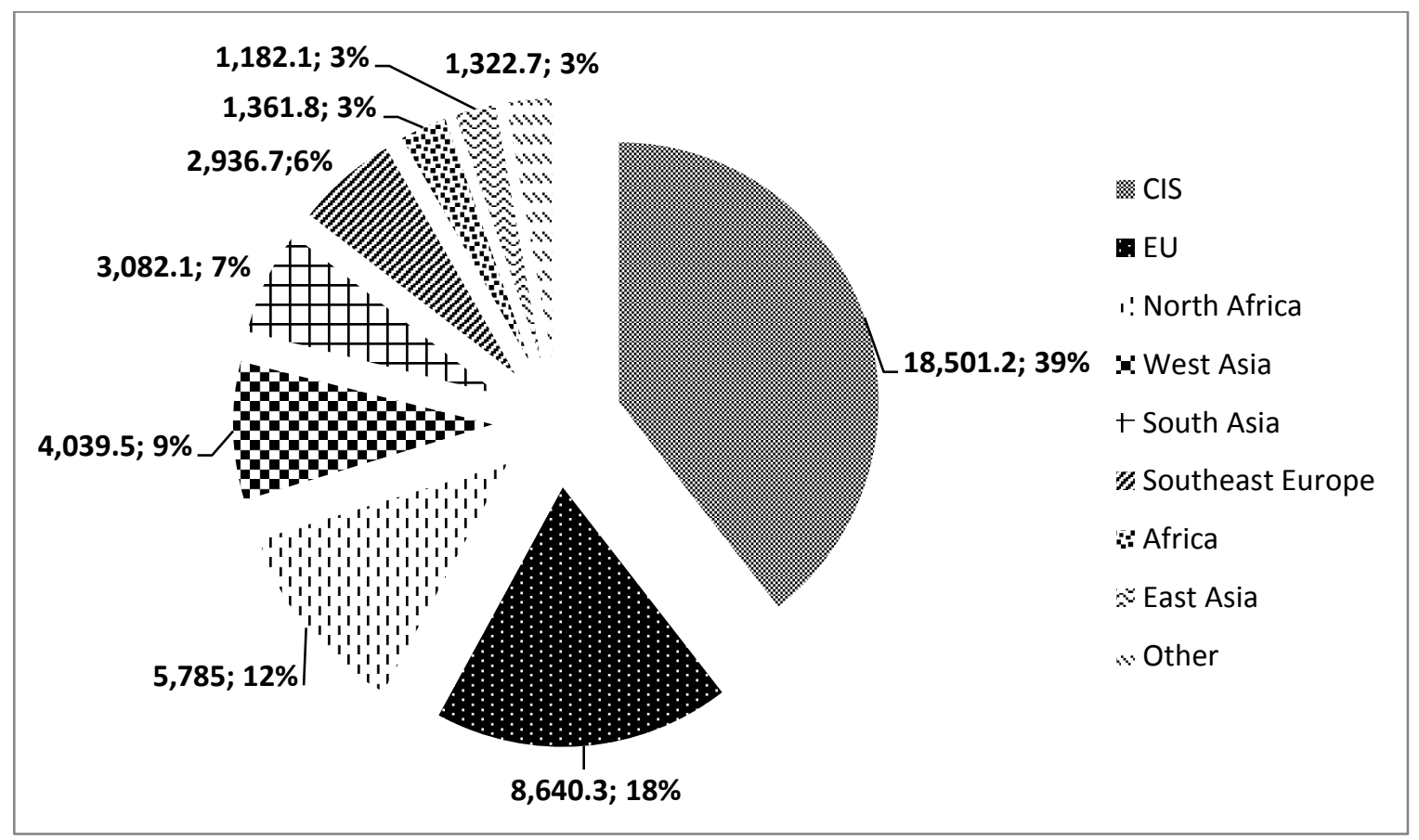

Source: fDi Intelligence from the Financial Times Ltd. Author's calculations.

\subsection{Distribution of Greenfield FDI among Countries}

Figures 9.3 and 9.4 show the value and number of investments by TMNCs among the EU countries, respectively. However, in terms of the value of investments, Bulgaria, which has the largest Turkish minority population in the Balkans, and Romania together attracted over 5 
billion US dollars, or about $60 \%$. Germany, which hosts the largest Turkish population in Europe, attracted the third largest TMNC greenfield investments in the EU (970 million US dollars or $11 \%$ ), and Romania received the highest employment and investment in value. They are followed by Germany, France and Greece. Apparently, historical, cultural and geographic proximity also informed TMNC internationalisation in these countries.

Figure 9.3: Distribution of non-financial TMNC Investments in EU Countries (Number of Investments)

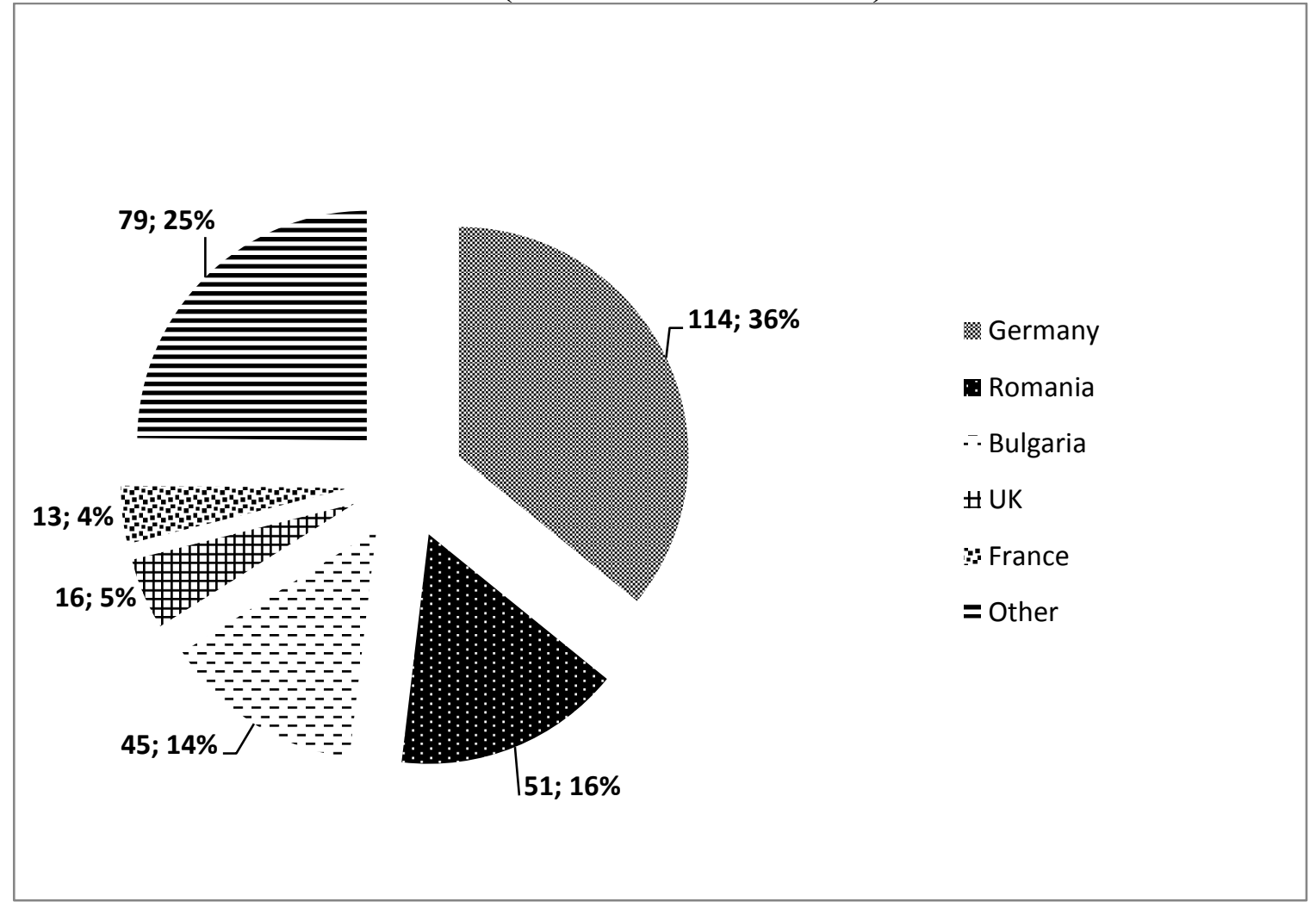

Source: fDi Intelligence from the Financial Times Ltd. Author's calculations.

Figure 9.4: Distribution of non-financial TMNCs Investments in EU Countries (2003-2013, Value of Investments - Million USD) 


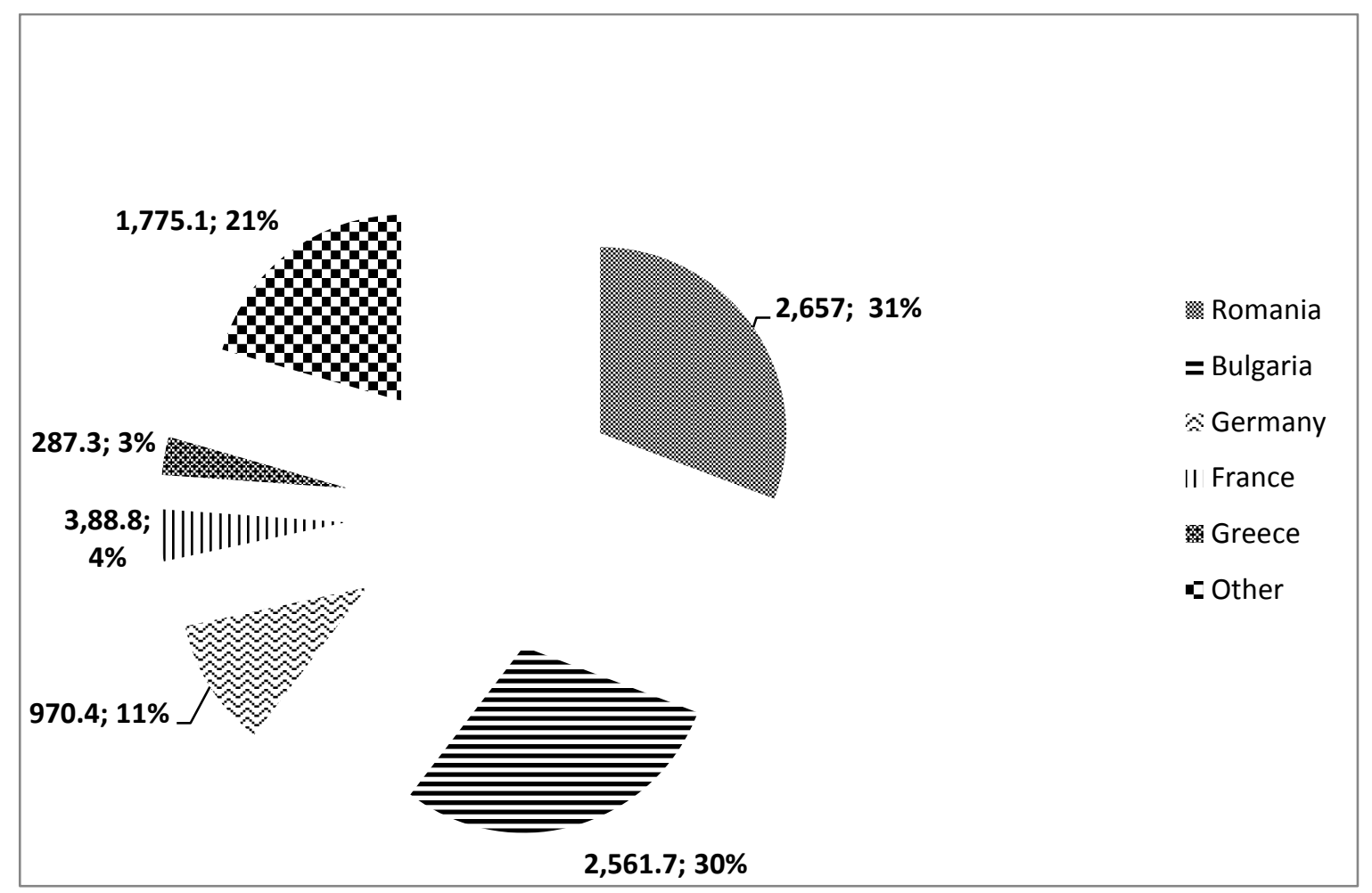

Source: : fDi Intelligence from the Financial Times Ltd. Author's calculations.

It is interesting to note that between 2003 and 2013, the top ten countries, ranked by the number of projects, attracted about a total of 20 billion US dollars in TMNC greenfield investments (including both financial and non-financial firms), which constituted about $50 \%$ of total greenfield investments (fDi Intelligence Database 2013). More interestingly, $96 \%$ of these investments were in developing and transition economies, whilst two developed economies, Germany and the US each had only a $2 \%$ share among these top 10 destinations. The number of investments by TMNCs in Germany reached 114 (or 36\%) which was followed by Romania (51 or $16 \%$ ) and Bulgaria (45 or $14 \%$ ).

\subsection{Sectoral Distribution of Greenfield Investments by non-financial TMNCs}

As Figure 9.5 shows, between 2003 and 2013, the highest value of investment was in the real estate sector ( 11 billion US dollars or $25 \%$ ). It was followed by coal, petroleum, and natural resources (6.9 billion US dollars or 15\%), textile (4 billion US dollars, or 9\%), hotel 
management and tourism $(2.7 \%$ US dollars or $6 \%)$ and construction and building materials $(2.2$ billion US dollars or 5\%).

\section{Figure 9.5: Sectoral Distribution of non-financial TMNC investments (2003-2013, Value of Investments - Million USD)}

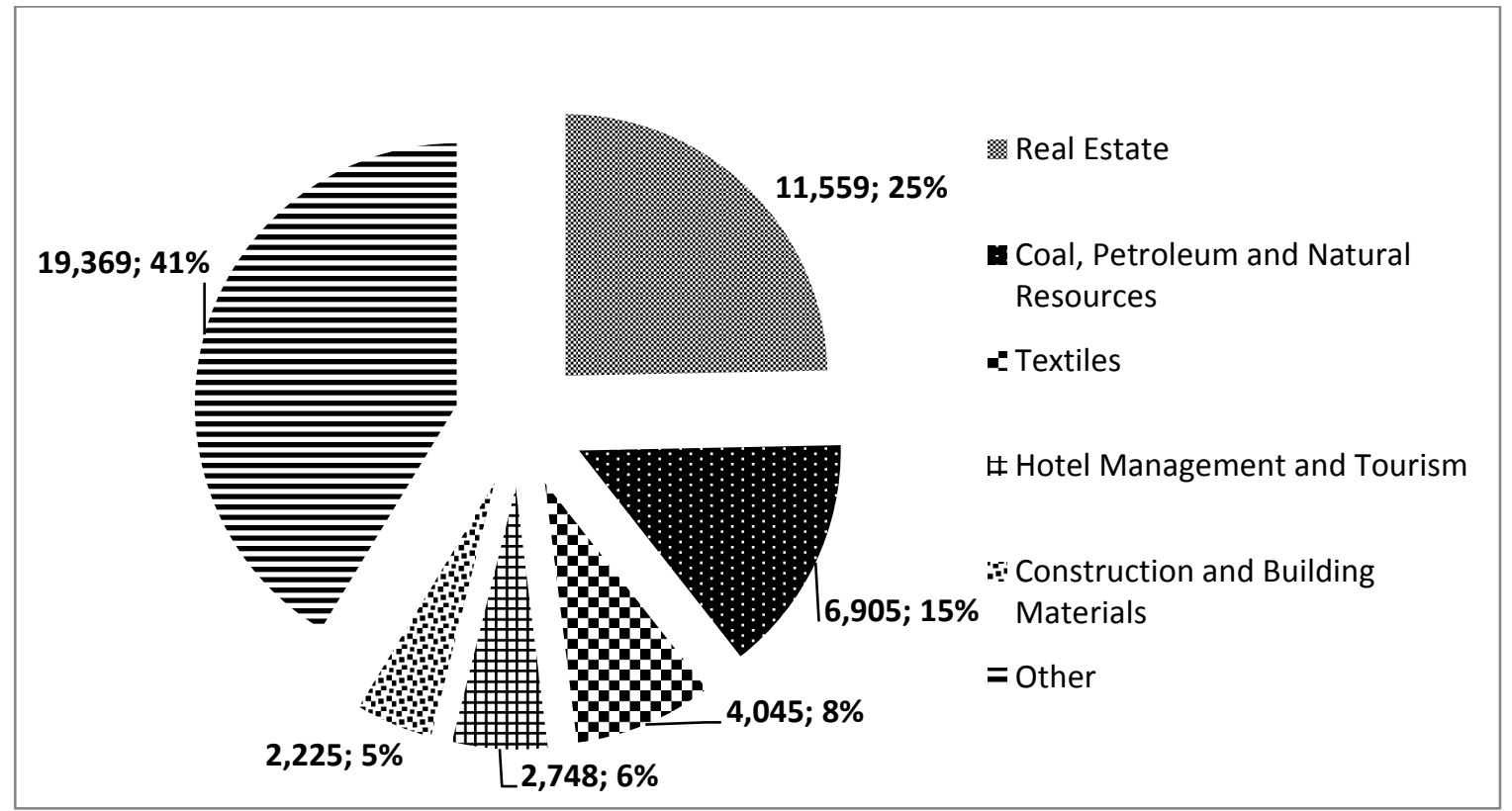

Source: fDi Intelligence from the Financial Times Ltd. Author's calculations.

What do we know about the distribution of these top three sectoral investments of TMNCs' across regions and countries? The fDi database shows that the EU is the second highest recipient of the real estate investments ( 1.7 billion US dollars or $15 \%$ of the total) after CIS countries ( 7.2 billion US dollars or $62 \%$ ). The EU is also the third largest recipient of textile investments from TMNCs (443 million US dollars or 11\%). However, the EU receives only 263 million US dollars (or 4\%) of TMNC investments in Coal, Petroleum, and Natural Resources. Turkish investors lean towards neighbouring CIS countries and transition economies in Europe, especially countries such as Bulgaria, Romania, and Russia in the real estate, food, and mining sectors, where they have FSAs and aim to accesses host country CSAs.

Figure 9.6: The largest TMNC investments in EU by sector 


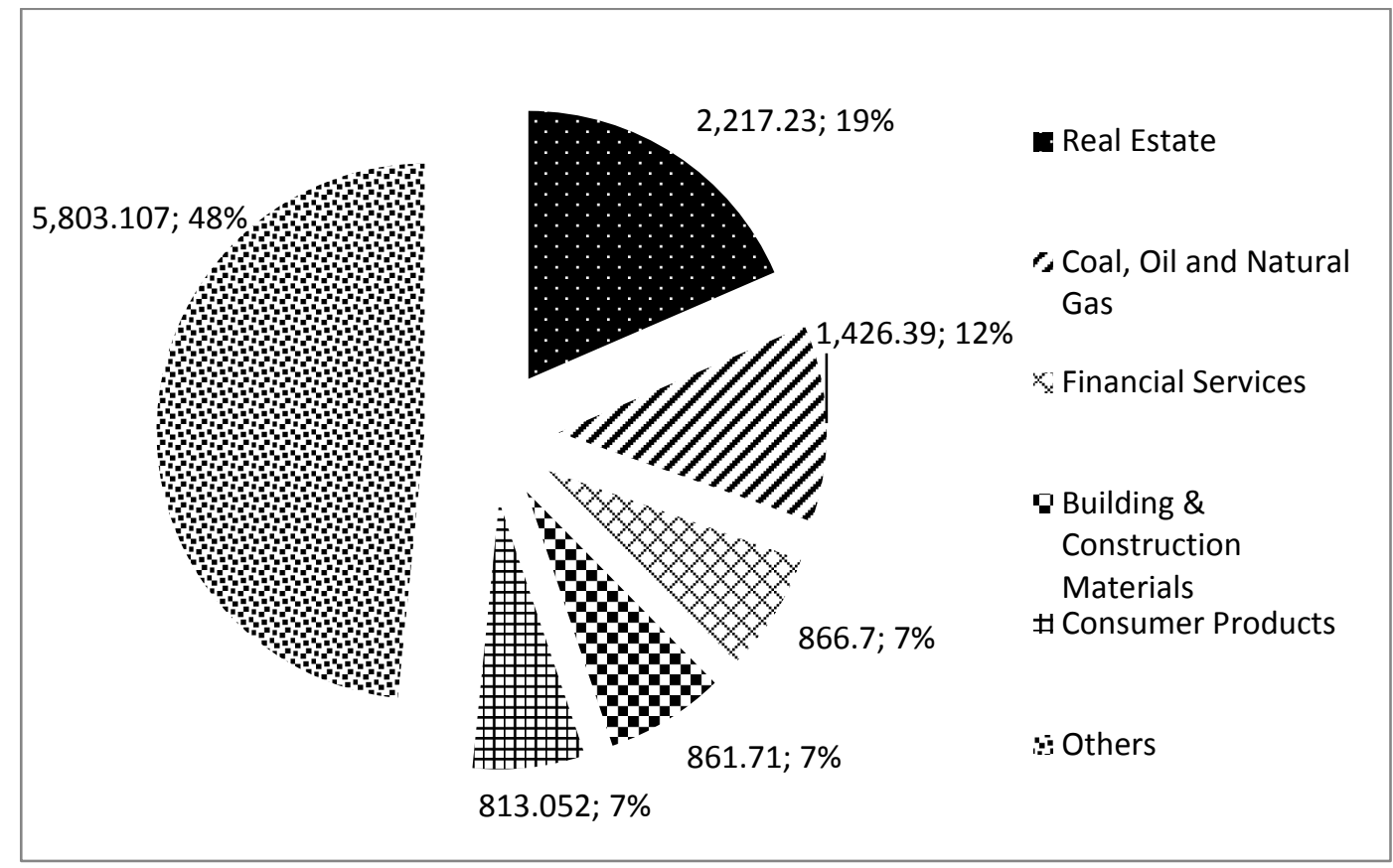

Source: fDi Intelligence from the Financial Times Ltd. Author's calculations.

As Figure 9.6 shows, real estate, and coal, oil and natural gas are the top two sectors in TMNC investments in the EU. It is interesting to note that financial services, building and construction materials, and consumer products each have a 7\% share in TMNC investments.

\subsection{Top 10 non-financial TMNCs in Greenfield Investments}

Table 9.3 shows 10 TMNCs that have made the highest value of international investments between 2003 and 2013. They mostly originate from Istanbul, and have created over 54 thousand jobs, with nearly 15 billion US dollars' worth of investment in nearby transition economies and developing countries. Investments were primarily targeted towards construction projects in the real estate industry. It is also shown that the investments by these companies constitute between $20 \%$ and $40 \%$ of the total investments made by Turkish investors in a given year. In contrast to MNC's from BRIC countries, which mostly invest in developed 
European markets such as the UK, Germany, and France, most of the TMNCs invest in transition and developing economies. As shown above, these investments are concentrated in Bulgaria and Romania.

A closer look at the TMNC sectoral activities in Bulgaria and Romania shows that TMNCs invest in banking, insurance services, chemicals, home appliances, textile, logistics, parks, residential, and hotel sub-sectors. Specifically, Romania is a significant market for Turkish real estate investments. Bulgaria and Romania's EU membership has been a major structural event that opened a window of opportunity to Turkish construction firms to undertake some of the EU-funded infrastructure investments in these countries.

Table 9.3: Top 10 non-financial TNCs in Terms of value of capital investments, 2003-2013 (Million USD)

\begin{tabular}{|c|c|c|c|c|c|}
\hline $\begin{array}{l}\text { Investor } \\
\text { Company }\end{array}$ & Home City & $\begin{array}{l}\text { Jobs } \\
\text { Created } \\
\text { (person) } \\
\end{array}$ & $\begin{array}{l}\text { Value of } \\
\text { Investment } \\
\text { (million USD) }\end{array}$ & Sectors & $\begin{array}{l}\text { Host Countries (Year, number of } \\
\text { investments) }\end{array}$ \\
\hline Ramenka & Istanbul & 21,826 & 2,452 & $\begin{array}{l}\text { Food and Tobacco, } \\
\text { Real Estate }\end{array}$ & $\begin{array}{l}\text { Kazakhstan }(2009,1), \text { Russia } \\
(2003,11 ; 2004,3 ; 2005,18 ; 2006,4 ; \\
2013,1)\end{array}$ \\
\hline Rixos Hotels & Antalya & 3,389 & 2,061 & $\begin{array}{l}\text { Hotels \& Tourism, } \\
\text { Leisure \& Entert. }\end{array}$ & $\begin{array}{l}\text { Austria }(2007,1) ; \text { Azerbaijan }(2012, \\
\text { 1); Bahrain }(2010,1) ; \text { UAE }(2008,2 ; \\
2011,1 ; 2012,1) ; \text { Croatia }(2007,1) ; \\
\text { Montenegro }(2013,1) ; \text { Kazakhstan } \\
(2005,1 ; 2009,1 ; 2013,1) ; \text { Libya } \\
(2010,1) \text {; Egypt }(2012,1) ; \text { Russia } \\
(2008,1) ; \text { Ukraine }(2005,1)\end{array}$ \\
\hline Enka & Istanbul & 4,625 & 1,847 & $\begin{array}{l}\text { Real Estate, Natural } \\
\text { Resources }\end{array}$ & $\begin{array}{l}\text { Russia }(2003,1 ; 2008 ; 2), \text { Tajikistan } \\
(2006,1)\end{array}$ \\
\hline Enisa Group & Istanbul & 161 & 1,819 & $\begin{array}{l}\text { Coal, Oil and } \\
\text { Nat.Resources }\end{array}$ & Morocco $(2011,1)$ \\
\hline Migros & Istanbul & 4,388 & 1,614 & $\begin{array}{l}\text { Real Estate and } \\
\text { Entertainment }\end{array}$ & $\begin{array}{l}\text { France }(2004,1) ; \operatorname{Iran}(2003,1), \\
\text { Macedonia }(2003,2 ; 2006,1) ; \text { Syria } \\
(2003,1) ; \text { Ukraine }(2003,1)\end{array}$ \\
\hline $\begin{array}{l}\text { Renaissance } \\
\text { Construction }\end{array}$ & Istanbul & 11,761 & 1,548 & $\begin{array}{l}\text { Real-Estate and } \\
\text { Entertainment }\end{array}$ & Russia $(2005,1 ; 2008,1 ; 2010,4)$ \\
\hline $\begin{array}{l}\text { Hakkan Mining } \\
\text { and Generation } \\
\text { Industry and Trade }\end{array}$ & Istanbul & 345 & 1,095 & $\begin{array}{l}\text { Coal, Oil and } \\
\text { Nat.Resources }\end{array}$ & Ruanda $(2012,2)$ \\
\hline $\begin{array}{l}\text { Opus Project \& } \\
\text { Development }\end{array}$ & Not Spec. & 3,000 & 956 & Real Estate & Romania $(2007,1)$ \\
\hline Kastamonu Entegre & Istanbul & 4,241 & 945 & Wood Products & $\begin{array}{l}\text { Bosnia Herzegovina }(2003,1 ; 2007,1) \text {; } \\
\text { Bulgaria }(2006,1 ; 2011,1) \text {; Romania } \\
(2008,1) \text {; Russia }(2009,1)\end{array}$ \\
\hline Aria & Istanbul & 730 & 913 & Communications & $\begin{array}{l}\text { Germany }(2003,1) \text {; United Kingdom } \\
(2003,1) \text {; Czech Republic ( } 2003,1) ; \\
\text { Philippines }(2003,1) \text {; Hong Kong } \\
(2003,1) ; \text { Switzerland }(2003,1) \text {; Italy } \\
(2003,1) \text {; Russia }(2003,1) \text {; Singapore } \\
(2003,1) \text {; Taiwan }(2003,1)\end{array}$ \\
\hline
\end{tabular}

$\begin{array}{lll}\text { Total of top } 10 & 54,466 & 15,250 \\ \text { Total OFDI performed by Turkish } & & \\ \text { MNCs } & 196,014 & 46,851\end{array}$




\section{Acquisitions by TMNCs}

Figure 9.7: Yearly Distribution of value and number of TMNC Acquisitions (2000-2013)

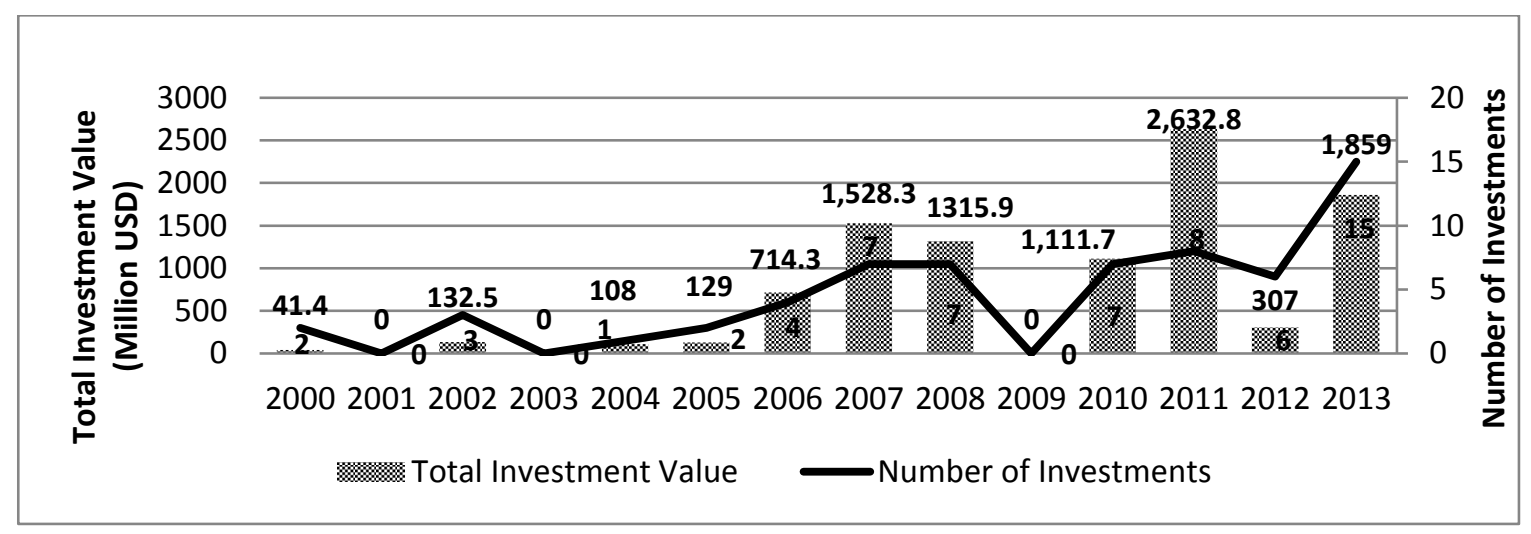

Sources: Thomson Reuters Mergers and Acquisitions Database and Deloitte Turkish Outbound M\&A Review 2012-2013.

Figure 9.7 shows the distribution of the number and value of the top 62 TMNC acquisitions whose value exceeded 10 million US dollars between 2000 and 2013. These TMNCs' had about 9.9 billion US dollars in acquisitions, which constituted $72 \%$ of the total investments. During this period, TMNC acquisitions increased 44 times, from about 41 million US dollars to 1.8 billion US dollars. 2001, 2003, and 2009 were the years during which no such investments were made. The 2001 Turkish economic crisis and the effects of the global financial crisis in 2009 were the main reasons for the absence of investments in these years. 2011 marked the highest investments in value, with 2.6 billion US dollars.

Here the focus is on the acquisitions of TMNCs whose majority shareholders are Turkish citizens. During the acquisition deals, TMNCs in general prefer $100 \%$ ownership or majority ownership. Some firms initially acquire $100 \%$ ownership of their investees, while others make subsequent investments to increase their shares to $100 \%$ or a majority position. Most of these firms are family-owned companies, which have a tendency to have $100 \%$ ownership of the acquired firm. However, some of the TMNCs prefer to be cautious in new 
markets and engage in partnerships with local firms rather than outright ownership. There are two main reasons: (1) This is because a partnership option is less costly in case the company needs to exit the market; and/or (2) to overcome the liability of foreignness (i.e., additional costs experienced abroad arising from, for example, limited local knowledge). Some TMNCs that enter the new markets through partnerships make further investments for full ownership in following years. Finally, it should be noted that most of these TMNCs are holding companies; conglomerates operating in a wide range of sectors in Turkey. Holding company structure enables TMNCs to reduce 'transaction costs' by creating internal markets inside the firm.

\subsection{Geographical Distribution of Acquisitions by TMNCs}

Figure 9.8: Distribution of the Value of the Mergers and Acquisitions among Economic Regions (2000-2013, Value of Investments - Million USD)

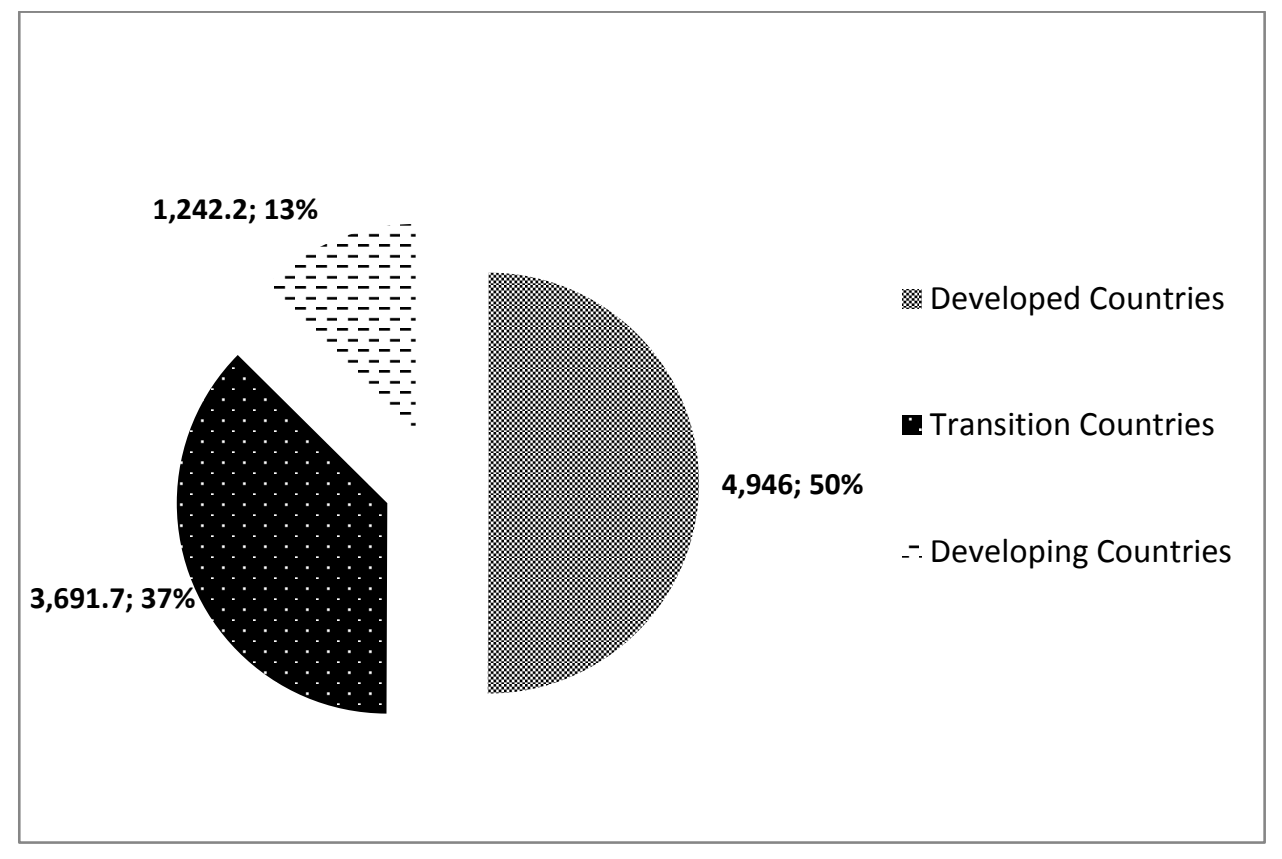

Source: Thomson Reuters Mergers and Acquisitions Database and Deloitte Turkish Outbound M\&A Review $2012-2013$

Figure 9.8 shows the distribution of value of investments among countries with different levels of economic development. Accordingly, unlike greenfield investments, developed 
countries host half of the TMNC acquisitions (4.9 billion US dollars or 50\%). They are followed by developing countries (3.7 billion US dollars or 37\%) and transition economies (1.2 billion US dollars or 13\%).

\section{Figure 9.9: Geographical Distribution of the Value of the TMNC Acquisitions (2000-2013, Value of Investments - Million USD)}

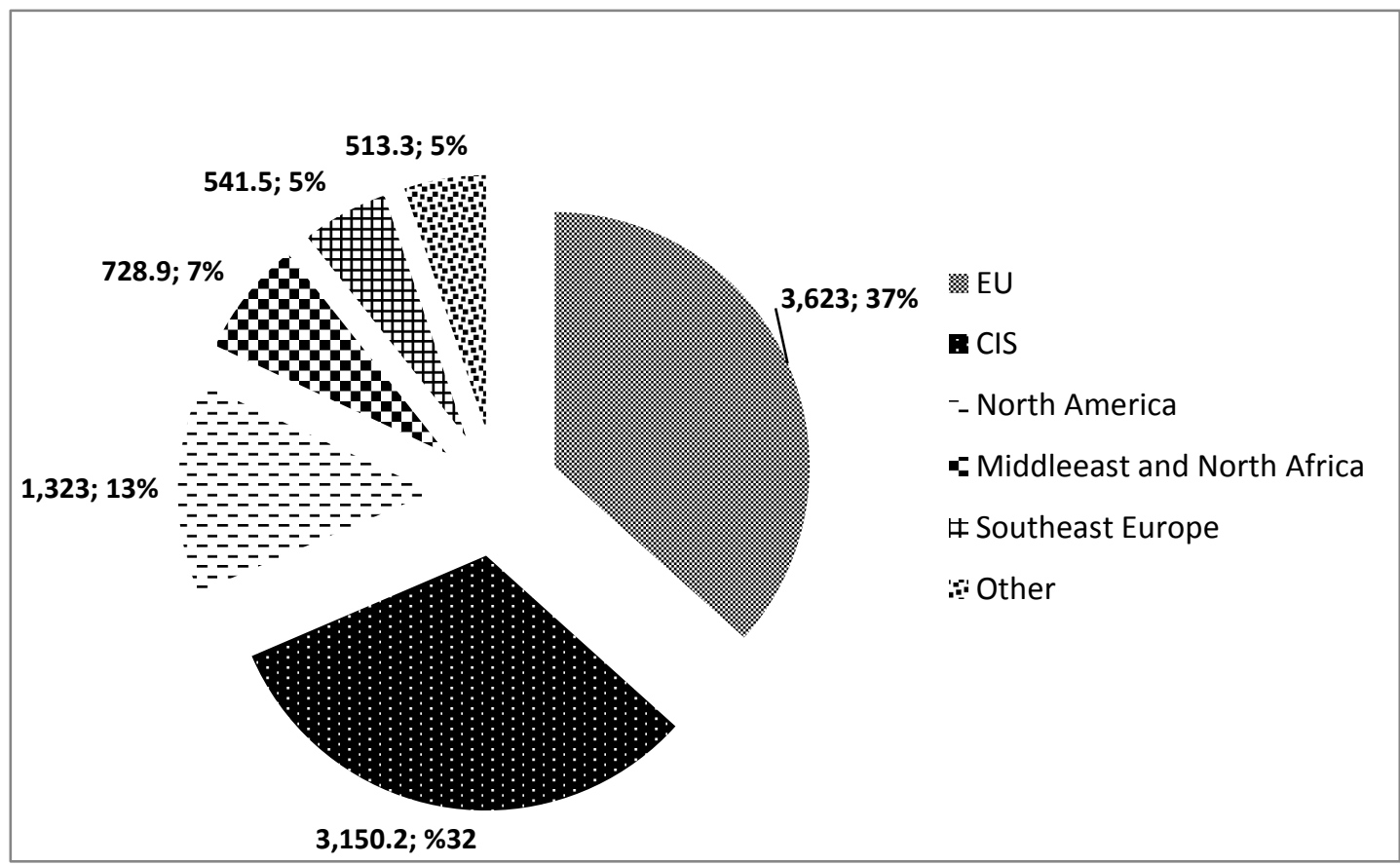

Sources: Thomson Reuters Mergers and Acquisitions Database and Deloitte Turkish Outbound M\&A Review 2012-2013.

Figure 9.9 shows the geographical distribution of the value of acquisitions by TMNCs. The EU is the most popular location in terms of value (3.6 billion US dollars or $37 \%$ ) of investments. TMNCs prefer operation in developed EU countries to improve their skills in branding, technology, R\&D, design, and management. The EU is followed by North America, South Asia, CIS, and Southeast Europe. CIS countries are not a very attractive destination for TMNC acquisition activities, as opposed to their popularity in Greenfield investments. Acquisitions in these regions are mainly motivated by TMNCs' desire to reach local markets 
and raw materials, by using their firm-specific advantages such as managerial experience and technology.

Figure 9.10 shows the distribution of the top 62 TMNC acquisitions, with special reference to target countries. Russia attracts the highest value of investments (2.6 billion US dollars, or $26 \%$ of the total), Holland (i.e., the Kingdom of Netherlands) and the US (each with 1.3 billion US dollars or $13 \%$ ).

Figure 9.10: Distribution of the Value of TMNC Acquisitions among Target Countries (2000-2013, Value of Investments - Million USD)

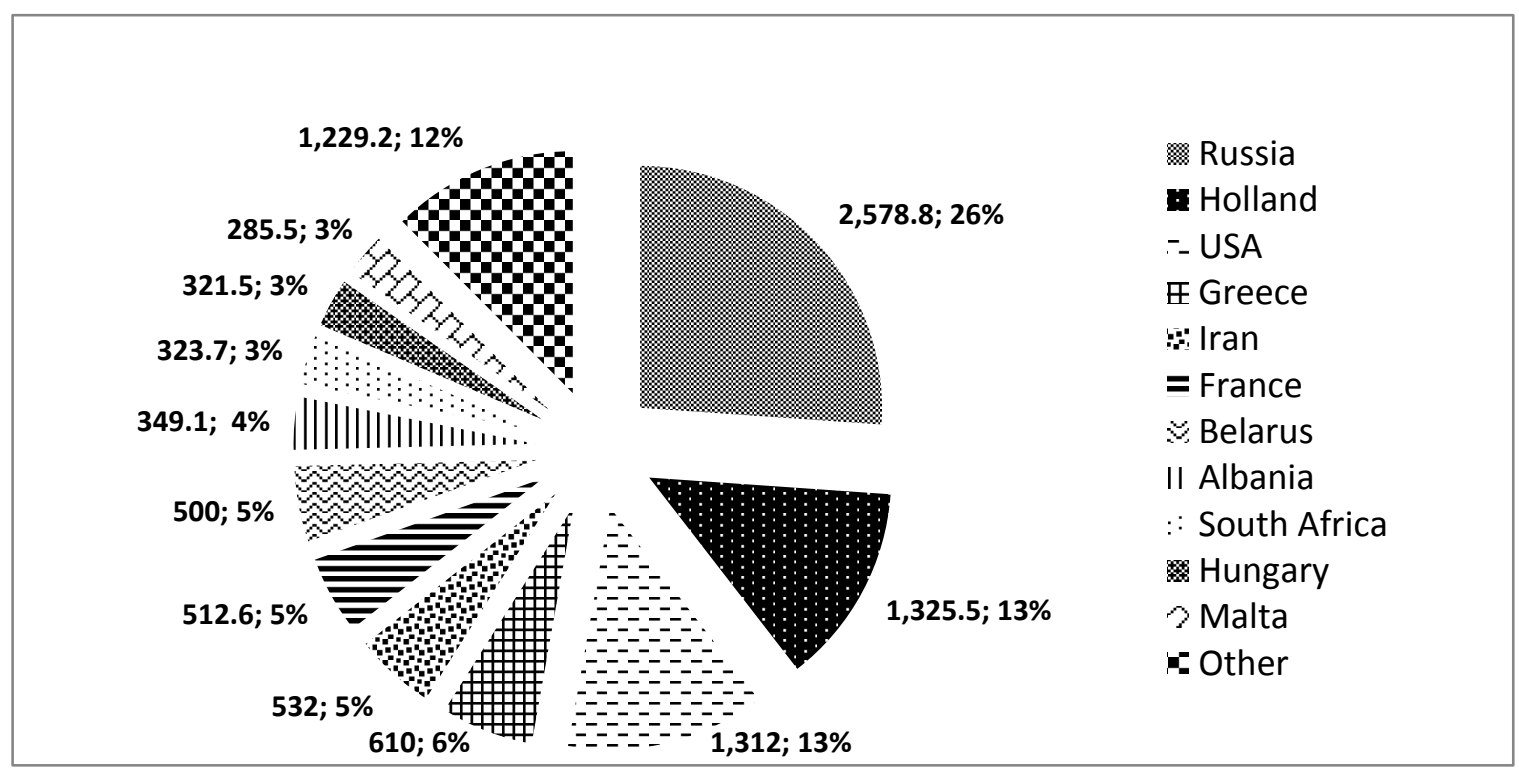

Source: Thomson Reuters Mergers and Acquisitions Database and Deloitte Turkish Outbound M\&A Review 20122013.

\subsection{Sectoral Distribution of the Acquisitions by TMNCs}

Figure 9.11 shows the sectoral distribution of the acquisitions of TMNCs. The highest investments in value were in the food and beverages (3.4 billion US dollars or 34\%), telecommunication (931 million US dollars or 9\%), and banking and finance (827 million US dollars or $8 \%$ ) sectors. How do these top three sectors score in the EU? The EU is the top destination for TMNC acquisitions in banking (750 million US dollars or 91\%). The EU's share in the telecommunications acquisitions is 270 million US dollars (or 29\%). This is followed by 
acquisitions in the food and beverages sector which attracts 200 million US dollars in investments (or $6 \%$ of the total in this sector).

Figure 9.11: Sectoral Distribution of the TMNC Acquisitions (2000-2013, Value of Investments - Million USD)

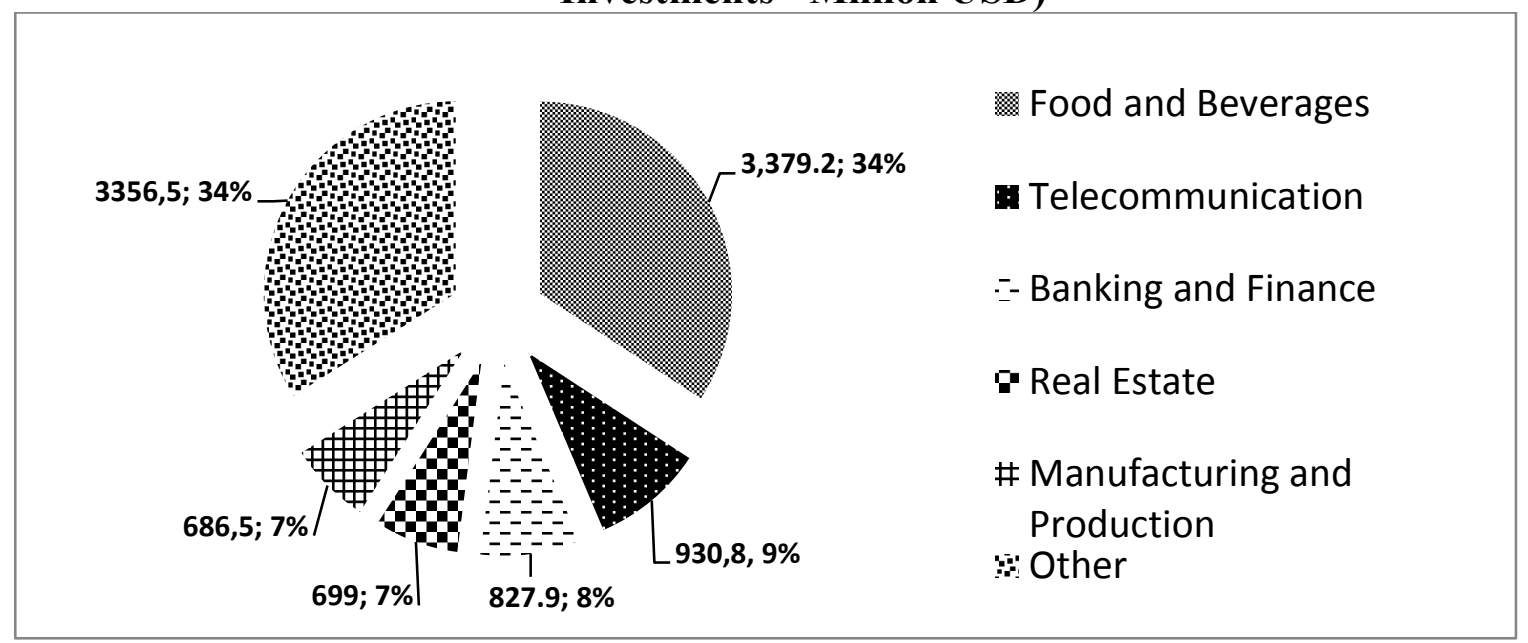

Source: Thomson Reuters Mergers and Acquisitions Database and Deloitte Turkish Outbound M\&A Review 20122013.

Table 9.2: Top 10 Turkish acquirers between 2000-2013

\begin{tabular}{|c|c|c|c|c|c|c|}
\hline Order & $\begin{array}{c}\text { Acquisition } \\
\text { value } \\
\text { (million } \\
\text { USD) }\end{array}$ & Target Company & Sector & $\begin{array}{l}\text { Target } \\
\text { Country }\end{array}$ & $\begin{array}{l}\text { Recipient } \\
\text { Company }\end{array}$ & $\begin{array}{l}\text { Purchased } \\
\text { Share }(\%)\end{array}$ \\
\hline 1 & 2,130 & $\begin{array}{l}\text { Russia and Ukraine } \\
\text { Businesses of } \\
\text { SABMiller (2011); Efes } \\
\text { Breweries International } \\
\text { (2010); CJSC Efes } \\
\text { Brewery (2013) }\end{array}$ & Food- Beverages & $\begin{array}{l}\text { Russia and } \\
\text { Ukraine } \\
\text { (2011); } \\
\text { Holland } \\
\text { (2010); } \\
\text { Russia } \\
(2013)\end{array}$ & Anadolu Efes & $\begin{array}{c}100,00(2011) ; \\
26,00(2010) ; \\
9,00(2013)\end{array}$ \\
\hline 2 & $1,211.4$ & $\begin{array}{l}\text { CMA CGM SA (2010); } \\
\text { Chrome Division of } \\
\text { Mechel (2013); Malta } \\
\text { Freeport Terminals } \\
\text { (2011) }\end{array}$ & $\begin{array}{l}\text { Transporation, } \\
\text { Mining and } \\
\text { Infrastructure }\end{array}$ & $\begin{array}{l}\text { France } \\
(2010) ; \\
\text { Russia and } \\
\text { Kazakhstan } \\
(2013) ; \\
\text { Malta (2011) }\end{array}$ & $\begin{array}{l}\text { Yildırım Holding } \\
\text { Inc. }\end{array}$ & $\begin{array}{c}20,00(2010) ; \\
100,00(2013) ; \\
50,00(2011)\end{array}$ \\
\hline 3 & 1,071 & $\begin{array}{l}\text { Godiva Chocolatier Inc } \\
(2007) ; \\
\text { DeMet's Candy } \\
\text { Company (2013) }\end{array}$ & Food- Beverages & US & Y1ldız Holding Inc. & 100,00 \\
\hline 4 & 598 & Astir Palace (2013) & Real-Estate & Greece & Doğuş Holding & $\mathrm{n} / \mathrm{a}$ \\
\hline 5 & 580 & $\begin{array}{l}\text { Finans Intl Holding NV } \\
\text { (2006) }\end{array}$ & Banking- Finance & Holland & Fiba Holding Inc. & 100,00 \\
\hline 6 & 532 & $\begin{array}{l}\text { Razi Petrochemical } \\
\qquad(2008)\end{array}$ & $\begin{array}{l}\text { Petrochemical } \\
\text { Industry }\end{array}$ & Iran & $\begin{array}{l}\text { Gübretaş; Tabosan; } \\
\text { Asia Gas Energy }\end{array}$ & 83,70 \\
\hline 7 & 500 & $\begin{array}{c}\text { Belarusian Telecom } \\
\text { (2008) }\end{array}$ & Telecommunication & Belarus & Turkcell & 80,00 \\
\hline
\end{tabular}




\begin{tabular}{|c|c|c|c|c|c|c|}
\hline 8 & 361.2 & $\begin{array}{c}\text { Defy Appliances } \\
\text { Limited (2011); Arctic } \\
\text { (2002) }\end{array}$ & $\begin{array}{l}\text { Manufacturing and } \\
\text { Household } \\
\text { Electronics, Durable } \\
\text { Goods }\end{array}$ & $\begin{array}{l}\text { South Africa } \\
(2011) ; \\
\text { Romania } \\
(2002)\end{array}$ & Arçelik Inc. & $\begin{array}{l}100,00(2011) ; \\
57,29(2002) ; \\
33,85(2002)\end{array}$ \\
\hline & 336.5 & Trader Media East Ltd & Media- Advertising & Holland & Hürriyet Invest B.V. & 67,30 \\
\hline 10 & 304.2 & $\begin{array}{l}\text { Al Waha }(2012,2013) \text {; } \\
\text { Coca Cola Beverages } \\
\text { Pakistan }(2008) \text {; Coca } \\
\text { Cola Beverages Iraq } \\
\text { Limited }(2011) \text {; Coca } \\
\text { Cola Almaty Bottlers } \\
\text { LLP (2007) }\end{array}$ & Food- Beverages & $\begin{array}{l}\text { Iraq (2011, } \\
\text { 2012, 2013); } \\
\text { Pakistan } \\
(2008) ; \\
\text { Kazakhstan } \\
(2007)\end{array}$ & $\begin{array}{l}\text { Coca Cola Beverage } \\
\text { manufacuring Inc. }\end{array}$ & $\begin{array}{c}\text { n/a (2012); } \\
49,00 \text { (2008); } \\
70,00(2011) ; \\
12,04 \text { (2007); } \\
15,00 \text { (2013) }\end{array}$ \\
\hline
\end{tabular}

Sources: Thomson Reuters Mergers and Acquisitions Database and Deloitte Turkish Outbound M\&A Review 2012-2013.

Table 9.2 shows the top 10 TMNCs which had the highest value of acquisitions between 2003 and 2013. The acquisitions of these firms totalled 7.6 billion US dollars, which constituted $77 \%$ of the sum of the largest 62 TMNC acquisitions worldwide. In other words, there is relative concentration of such investments in a relatively small number of firms. It should be noted that these firms operate oligopolistic markets in Turkey, exploiting CSAs such as economies of scale and scope and non-price competition. There were 43 deals (or $58 \%$ of the total) completed between 2010 and 2013. Arguably, the 2008 Global Financial Crisis and the Eurozone Crisis posed acquisition opportunities for TMNCs. Half of these deals were in the food processing, banking and finance, and telecommunications sectors.

Anadolu Efes has a strong concentration in the CIS region and Russia in particular (for a detailed discussion TMNCs in Russia, see Bakır and Acur 2016). The remaining top two TMNCs included Yildirim Holding and Yildiz Holding which will be discussed below.

\section{Motivations and Strategies of TMNCs Investments and Structural Complementarities}

\subsection{Competitive advantages and motivations of TMNCs}

Yildiz Holding is the biggest diversified food group by revenue in Central and Eastern Europe, Africa, and the Middle East, with about 7 billion US dollars in total sales in 2013. Its two high profile acquisitions can be considered as an example of an effort towards a global 
consolidation strategy of EMNCs. Y1ldız Holding acquired the Belgian chocolate maker Godiva from American Campbell Soup Co. in 2007 for 850 million US dollars. This acquisition was the biggest single acquisition deal executed by a TMNC at the time. Godiva's revenues increased by 10 percent each year following the acquisition, reaching 765 million US dollars. The company significantly increased its marketing, infrastructure, and staff investments by 40\%. It increased its sales in US and Japan. Building on Yildiz group's knowledge, networks, and expertise, Godiva identified China, the Middle East, North Africa, and Turkey as new markets. Indeed, it entered new markets including Australia, China, Saudi Arabia, Korea, Macau, and Turkey. Its international sales increased from 43\% in 2008 to $52 \%$ in 2013.

Following the acquisition, Yildiz Holding entered 10 new countries, increased its branches from 480 to over 600 , the number of points of sale increased from 10 thousand to over 32 thousand. Its sales also increased from 450 million US dollars in 2007 to 765 million US dollars (Forbes, March 2014: 64).

The success of the acquisition was due to "partnering" -"keeping an acquisition structurally separate and maintaining its own identity and organization"- rather than traditional post-acquisition integration:

Instead of rushing to integrate businesses they've bought overseas, they've allowed their acquisitions to continue operating independently, almost as if there had been no change of ownership. Each organization focuses on what it does best even as it learns to use the resources and capabilities of the other to achieve its goals. (Kale, Digh and Anand 2009)

"Partnering" has been a key step for Yildiz Holding towards a 'global consolidator' strategy, which "is characterized by FSAs in operational excellence combined with restructuring/turnaround capabilities" (Williamson and Zeng 2009: 87; Ramamurti and Sigh 2009: 140). Here, Yildiz Holding and Godiva have developed effective organisational mechanisms that transferred their unique resources and capabilities into FSAs of one another. The success of this acquisition lies in the transfer of Yildiz Holding's FSAs obtained in developing markets to Godiva, and Godiva's transfer of FSAs obtained in advanced developed 
markets to Yildiz Holding. In the words of Y1ldı Holding's deputy chairman Ali Ülker "we learnt how to do a global business. We had great benefits in the context of learning [following the acquisition of Godiva]" (Harvard Business Review, November 2012). Godiva President and Chief Executive Officer (CEO) Jim Goldman at the time referred to the transformation that Godiva had undergone since it was acquired by Y1ldı Holding in 2007. He highlighted investments made in innovation in 2013 and noted that

I am certainly sure of the fact that Godiva reached success with the right partner. We came across the strongest and newest marketing programs during the restructuring of the business and we expanded our business to new destinations, such as China, which helped to increase the bulk of our sales as well as gain experience (Cited in Today's Zaman 20 December 2011).

This point adds a new dimension to the so-called new internationalisation theory that FSAs of the parent company obtained at home can further FSAs of a subsidiary to operate in new markets and benefit from structural complementarities that reinforce their internationalisation strategies.

In other words, Yildiz Holding acquired unique resources and dynamic capabilities from Godiva, such as a global brand, managerial and marketing skills, and knowledge and experience. Godiva also acquired FSAs from Yildiz Holding, such as consumer insights, operating in weak institutional environments, and access to cash. This argument - a mature MNC (i.e., Godiva) acquires FSAs from an EMNC (i.e., Yildiz Holding) - challenges the conventional wisdom that EMNCs

use international expansion as a springboard to acquire strategic resources and reduce their institutional and market constraints at home. In so doing, they overcome their latecomer disadvantage in the global stage via a series of aggressive, risk-taking measures by aggressively acquiring or buying critical assets from mature MNEs to compensate for their competitive weaknesses. (Luo and Tung 2007: 481)

In fact, developed country MNCs as subsidiaries of EMNCs can acquire FSAs from their parents.

Yildiz Holding took another major step towards its generic global consolidator strategy when it bought United Biscuits in November 2014 from private equity owners Blackstone Group and PAI Partners for about 2 billion pounds (3.2 billion US dollars). This made Yildiz 
the world's third-biggest biscuit maker. In the words of CEO of Yildiz Holding, Murat Ulker: "We want to grow United Biscuits to be a global player as part of Yildiz. This will include enhancing its position in the UK, where Yildiz currently has minimal presence, so we will continue to invest in the UK and Europe" (Cited in Financial Times 3 November 2014, my italics).

TMNCs also explore FSAs in developed markets. For example, Turk Telekom acquired 100\% ownership of Invitel International in 2010 and therefore owned "one of Central and South eastern Europe's leading independent wholesale data and capacity service providers that operates in 16 European countries with its 27 thousand kilometres long optical fibre network" (Anadolu News Agency, 18 May 2010). A statement by Turk Telekom asserted that the investment in Austria aims at reaching the target company's FSAs and increasing Turk Telekom's international competitiveness to allow it enter new markets:

It was stated that Turk Telekom, which has an important position in terms of geographical connections, aims at improving this position by providing the access within Central and Eastern Europe and the access to the Middle Eastern and Asian markets and the Western European and American markets with this acquisition. Moreover, the statement also underscored that the acquisition will create synergy opportunities between Invitel International and Turk Telekom. (Anadolu News Agency, 18 May 2010)

Similarly, Sabanci Holding, the second largest conglomerate in Turkey, sought access to DuPont's FSAs through acquisitions. DuPontSA, the largest Polyester manufacturer in Europe, jointly established by Sabanci Holding and DuPont in 1996, is the leading producer of its sector in Europe. The CEO Celal Metin from Sabanc1 Holding, which acquired the full ownership of DuPontSA by an investment in 2005 in the US, stresses that they want to expand their market share by obtaining technology and brands: "We foresee that DuPontSA will grow profitably thanks to its high technology, world-renowned brands and 3.500 skilful employees and the entire industry will benefit from its quality goods and services" (Star Gazetesi, 9 October 2004). 
TMNCs also acquire firms with strong market penetration and exploit FSAs in emerging European and CIS countries. For example, Hurriyet AS, a Turkish publishing company, purchased Trader Media East Ltd. (TME) in 2007. Hurriyet is owned by Dogan Sirketler Grubu Holding A.S., which is one of the largest conglomerates in Turkey with investments in media, energy, manufacturing, and tourism. TME was one of the most important advertising agencies in Russia, CIS, and Eastern Europe. TME employs approximately 1,900 people in eight countries, namely Russia, Poland, Hungary, Croatia, Ukraine, Kazakhstan, Belarus and Lithuania. Hurriyet Invest BV, Hurriyet's subsidiary located in Holland, initiated this investment which was motivated by Hurriyet's desire to enter new markets in the online advertisement business sector through incorporating TME's knowledge, experience, and specialisation in high growth markets in Russia and CIS countries. Hurriyet's CEO Vuslat Dogan Sabanci noted that:

We believe that the merger between Hurriyet and TME will create the biggest online advertisement platform in the region. The acquisition will give Hurriyet better access to high-margin online advertising and strengthen its presence in fast growing central and eastern European markets. (Anadolu AjansiEnglish News, 4 January 2007)

Indeed, a year later, it has been noted that Hurriyet increased its operating income by $90 \%$ where 45\% was derived from TME's activities (Referans, 14 November 2008).

\subsection{Structural Complementarities}

Complex and interdependent interactions among context dependent structural and institutional complementarities and agency-level enabling conditions affect firm behaviour (Bakir, 2013). This section offers a brief assessment of interactions among structures and agents informing the realisation of investments. This nuanced view offers a new insight to FSA and CSA based analysis of firms' internationalisation activities. Specifically, although firms may be guided by FSAs and CSAs, the realisation of investment requires the existence of structural, 
institutional, and agency-level complementarities that reinforce a firm's motivations and strategies.

The acquisition of Godiva by Yıldız Holding, owner of diversified food company Ulker Group, in 2007 is an example demonstrating such interactions. A conventional IB explanation would consider this acquisition as a reflection of both inward and outward internationalisation strategy, which requires new brands, further management skills, technical know-how and access to new markets.

However, the investment deal would not have taken place without two main structural complementarities: the US sub-prime mortgage crisis and appreciation of the Turkish lira against the US dollar. These two structural complementarities reinforced Yildiz Holding's acquisition of Godiva. In the words of Yildiz Holding's CEO at the time:

Our biggest competitors were the financial investors and world's giants in chocolate sector which acquire valuable brands when they see it. ...In those days [before the auction day], the deal price was expected to be around 1.2-1.5 billion USD. There were two things that change the fate of this [acquisition] agreement. First, financial investors withdrew from the scene due to the credit crisis originating in the US financial markets. This was our biggest conjectural chance. [Second], depreciation of the US dollar against Turkish lira has offered an advantage to us. (Anka, 28 December 2007, emphasis added)

In other words, the motivations and strategies of Yildiz Holding were not sufficient conditions to deliver an investment deal unless they were backed by structural conditions. Thus, appreciation of the effect of such structural variables on outward investment helps us to understand when and why structural contexts complement FSAs and CSAs. One of the key agency-level enabling conditions behind the acquisition was, in the words of Ulker Group's head of board of directors, Murat Ulker, "we had enough money” (Anka, 28 December 2007).

TMNCs also benefit from structural factors such as the economic recession in Europe following the GFC and Euro crisis. These external shocks hit global trade, and thus firms operating in the shipping business. For example, Yildirim Group, the world's second largest chrome producer and operator in coal and metal, production and sale of fertilizer, mining and ferroalloys, shipping and ship buildings, and port management, bailed out heavily indebted 
shipping giant CMA CGM by acquiring 20 percent of the French firm for 500 million US dollars (380 million euros) in 2010. This was Yildirim's largest investment in Europe. CMA CGM was the world's third largest container operator and this acquisition contributed to Yildirim Group's horizontal integration strategy and profit. Yildirim has FSAs arising from its diverse activities ranging from energy trading and port operations to ferroalloy production, mining, and shipbuilding. Thus it was well positioned to control its supply chain. Therefore, the key FSA related to the acquisition included market information and knowledge of trends in the steel industry. In the words of Robert Yildirim, one of the owners and the Chairman of Yildirim,

\footnotetext{
We supply the steel industry with raw materials so we know whether they are doing well or not, we see their order books so when they are slowing down or going up, we are talking to them so then that affects the shipping...If we sign a deal, we know what the market will be looking like two months ahead. So when orders are cut that also affects shipping two months later, so we share this market information with CMA CGM. So we are saying we see the market this way and how it affects shipping, we tell them [CMA CGM] when to move their empty boxes - this is happening in the market, be careful, put your empty container in position, the market is going up. (cited in Port Finance International, 25 April 2012)
}

Yildirim Holing also explored FSAs from the acquisition. In the words of the chairman, "We can use the CMA CGM network to use the right people to reach the right people in other businesses...We can use CMA CGM as a logistics partner, it is a win-win investment for both parties, a perfect match" (ibid).

Further, structural complementarities such as the privatisation process also contributed to the internationalisation of TMNCs along with institutional complementarities and agencylevel enabling conditions such as FSAs. Gübretaş acquired Razi Petrochemical Co through Iran's first privatisation opportunity activity. This investment was a reflection of the vision of becoming a "globally branded pioneer in Turkey." Since 2006, the firm has followed the strategy of investing in countries with rich raw material resources. Gübretaş General Manager Osman Balta says the company plans to rehabilitate the inactive parts of Razi Petrochemical and increase the capacity utilization rate (Hazarworld, February 2013). In subsequent years, Gubretas had further expansion of existing investments. Similarly, Sise Cam also acquired two 
state-owned glass factories during the privatisation process in Bulgaria. For example, Sise Cam had undertaken a joint acquisition with a Belgian company, Solvay Group, in 1997 to acquire one of the largest glass producers 'de Sodi-Devnya with a 35 million US dollar investment. Like Gubretas, this was followed by Sise Cam's greenfield investments for the expansion of glass production in the subsequent years. Similarly, Turk Telekomikasyon AS's and Calik Grubu's investments in privatisation processes in Azerbaijan and Albania are examples of investments based on such FSAs. Turk Telekominikasyon AS entered the Azeri market by acquiring a mobile network operator with around 3 million subscribers. The company's partnerships in Georgia, Kazakhstan, and Moldova operate as the largest GSM companies in their respective countries. These examples show that TMNCs exploit their firm-specific managerial and technological advantages obtained in Turkey in less developed markets.

In sum, acquisitions by TMNCs in developed countries are motivated by inward internationalisation strategies of reaching new markets through obtaining technology, market information, and brands. Acquisitions in developing countries aim at accessing new markets and lowering costs by using their firm-specific technological and managerial advantages.

\section{Discussion and Conclusions}

This chapter offered an analysis of the current trends, competitive advantages, and motivations of TMNC investments in Europe with special reference to greenfield investments and acquisitions. It focused on geographic and sectoral distribution of these investments with particular emphasis on FSAs, CSAs, and structural complementarities. It examined the extent to which key theoretical perspectives on the MNC internationalisation can explain outbound investments from a developing economy like Turkey.

TMNCs have their Greenfield investments in neighbouring geographies, especially in transition economies and developing countries. Only $22 \%$ of greenfield investments are located 
in developed economies. There has been sectoral concentration in the construction sub-sector of the real estate sector. Most of these investments are in Turkmenistan and Russia. Such investments are mostly related to infrastructure investments (e.g., roads, tunnels, and bridges), premises, airports, and hotels. TMNCs also have similar infrastructure investments in Bulgaria and Romania. TMNCs' greenfield investments are motivated by market-seeking (access to domestic markets as well as access to EU markets via exports) and cost-seeking FDI (e.g., tax advantages, access to raw materials and cheap labour) where these firms exploit their FSAs, such as managerial and market knowledge, expertise, and technology. Key CSAs include operating in oligopolistic industries, economies of scale and leadership in home market, geographical, cultural, and institutional proximity.

In contrast to greenfield investments, most TMNCs' acquisitions are in developed countries ( $72 \%$ of total investments). The EU is the most preferred region for these firms. Holland attracts the highest amount of investments in the EU. This is because it offers tax advantages and has extensive bilateral investment treaties, therefore Turkish firms incorporated in Holland (or subsidiaries of TMNCs) for fiscal considerations tend to use it as a home country for investing in other countries. Half of the acquisitions in Holland are concentrated in the manufacturing, banking and telecommunications sectors.

Although the main current theoretical lenses available in IB literature such as FSAs and CSAs are widely used for developed country MNC internationalisation, they are also useful in explaining the internationalisation behaviour of EMNCs, in particular TMNCs. Thus, this chapter focuses on the FSAs of TMNCs obtained from both home CSAs and host CSAs in understanding the motivations behind TMNC investments in Europe. It showed that some of the largest TMNCs are guided by various complementary motivations, including the exploitation and exploration of FSAs and CSAs in different times and contexts. They are also 
successful in relying on both FSAs obtained in home markets and FSAs obtained from host markets in their internationalisation activities.

TMNCs have inward and outward internationalisation strategies. In regard to inward internationalisation, their key motivation has been to access brand, technology, market knowledge, and managerial knowledge/expertise in developed markets. In doing so, TMNCs aim to build or strengthen their competitive advantages. The acquisition of FSAs helps these firms to access new markets. Thus, one of the main motivations has been to internalise proprietary firm-specific assets. When TMNCs acquire firms in transition and developing countries, they benefit from outward internationalisation to exploit their FSAs, such as relatively advanced managerial knowledge and technology. However, it should be noted that some of the TMNCs, such as Yildiz Holding and Yildirim Holding, have stakes in developed country MNCs and they also exploit their FSAs and home country. These family-owned diversified firms also utilise global consolidator strategies in their business activities.

It should also be noted that complementarities arising from structural contexts, such as the appreciation of the Turkish lira against major currencies during the GFC and Euro crisis, and financial difficulties of target companies in a crisis environment, have also contributed to TMNCs' acquisition activities. Finally, it would be interesting to investigate in detail whether these deals make respective TMNCs formidable global competitors. 


\section{Bibliography}

Akçaoğlu, E. (2005). Türk Şirketlerinin Dış Yatırımları: Saikler ve Stratejiler, Türkiye Bankalar Birliği, Ankara.

Anadolu Ajansı. (2010). 'Türk Telekom, Uluslararası Telekom Devini Satın Aldı', May 18.

Anadolu Ajansi-English News. (2007). 'Hurriyet to purchase trader media East', January 2.

ANKA Haber Ajansı. (2007). 'Godiva'yı almamızda kredi krizi ve değerli YTL önemli rol oynadı', December 28.

Brennan. L. ed. (2011). The Emergence of Southern Multinationals: Their Impact on Europe, London/New York: Palgrave Macmillan.

Bakir. C. (2013). Bank Behaviour and Resilience: The Effect of Structures, Institutions and Agents, Palgrave MacMillan.

Bakir. C. (2016). Turk Cok Uluslulari. Istanbul, Koc University Press. (forthcoming)

Bakir, C. and Acur, N. (2016). "Turkish Multinationals in Russia”, Liuhto, K., Sutyrin, S. ve Blanchard, J. eds.Foreign direct investment to and from Russia: Recent trends and international investment cooperation. London: Routledge (forthcoming).

Campbell, J. L. (2011). 'The U.S. financial crisis: Lessons for theories of institutional complementarity'. Socioeconomic Review, 9, 211-234.

Crouch, C. (2010). 'Complementarity', in Morgan, G., Campbell, J. L., Crouch, C., Pedersen, O. K. and Whitley, R. (eds), The Oxford Handbook of Comparative Institutional Analysis. New York: Oxford University Press, 117-137.

Cuervo-Cazurra, A. and Ramamurti, R. (2014). Understanding Multinationals from emerging markets. Cambridge, Cambridge University Press.

Demirbağ, M. and Yaprak, A. (eds). Handbook of Emerging Market Multinational Corporations. Cheltenham: Edward Elgar.

Dunning JH. (1988). Explaining International Production. Unwin Hyman: London, U.K.

Dunning, J.H. (1993). Multinational Enterprises and the Global Economy, Addison Wesley, New York.

Erdilek, A. (2003). A Comparative Analysis of Inward and Outward FDI in Turkey, Transnational Corporations, 12, 3, 79-105.

Erdilek, A. (2007). 'Outward Foreign Direct Investment by Enterprises from Turkey', Global Players from Emerging Markets: Strengthening Enterprise Competitiveness Through Outward Investment, UNCTAD; New York ve Cenevre. Pp. 147-162. 
Ernst and Young. (2014). EY's Attractiveness Survey Europe 2014: Back in the Game Available at http://www.ey.com/Publication/vwLUAssets/EY-2014-Europeanattractiveness-survey/\$FILE/EY-2014-European-attractiveness-survey.pdf

Financial Times. (2014). 'Blackstone and PAI seal sale of United Biscuits to Turkish group Yildiz', November, 3.

Forbes, 2014, 'En Zenginler Listesi’ s.64

Goldstein, A. (2007), Multinational Companies from Emerging Economies, London/New York: Palgrave Macmillan.

Harvard Business Review (2012). Istanbul, November

Guillén, M and García-Canal, E (2012). Emerging markets rule: Growth strategies of the new global giants, McGraw-Hill, New York

Hazarworld. (2013). 'Bölgenin Güçlü Oyuncusu Gübretaş', Available at http://www.hazarworld.com/201302/roportaj/bolgenin-guclu-oyuncusu-gubretas

Hennart, JF., (2012). 'Emerging Market Multinationals and the Theory of the Multinational Enterprise’, Global Strategy Journal, 2: 168-187.

Kale, Prashant. and Singh, Harbir. And Raman, P. Anand. (2009). 'Don't Integrate Your Acquisitions, Partner with Them'. Harvard Business Review.

Kaya, H. (2009). 'Unfavorable Business Environment and Foreign Direct Investment Activities of Turkish Manufacturing Firm', BDDK Bankacılık ve Finansal Piyasalar, 3, 1, 101-118.

Kaya, H. and Erden, D. (2008). 'Firm-specific Capabilities and Foreign Direct Investment Activities of Turkish Manufacturing Firms: An Empirical Study', Journal of Management Development, 27, 7, 761-777.

Kayam, S. ve Hisarcıklılar, M. (2009). 'Türkiye'den Çıkan Doğrudan Yatırımları Belirleyen Etmenler: 1992-2005', Işsletme, İktisat ve Finans, 24, 280, 47-70.

Khanna T, Palepu K. (2006). 'Emerging giants: building World class companies in developing countries.' Harvard Business Review 84(10): 60-69.

Klein, S. and Wocke, A. (2007). 'Emerging Global Contenders: the South African Experience', Journal of International Management, 13(3), .319-337.

Luo Y, Tung RL. (2007). 'International expansion of emerging market enterprises: a springboard perspective'. Journal of International Business Studies 38(4): 481-498.

Mathews JA. (2002). Dragon Multinational: A New Model for Global Growth. Oxford University Press: New York. 
Narula,R. and Dunning, J.H., (2010). 'Multinational enterprises, development and globalization: some clarifications and a research agenda'. Oxford Development Studies, 38(3), pp. 263-287.

Ramamurti, R. and Singh, J.V. (2009) Emerging Multinationals in Emerging Markets, Cambridge University Press, Cambridge.

Ramamurti, R. (2009). 'What have we learned about emerging market MNEs?'. In R. Ramamurti \& J. V.Singh (Eds.). Emerging multinationals from emerging markets. Cambridge: Cambridge University Press.

Ramamurti, R. (2012). 'What is really different about emerging market multinationals?' Global Strategy Journal, 2: 41-47.

Ramamurti (2013). 'Cross-border M\&A and competitive advantage of Indian EMNEs' in Williamson, P., Ramamurti, R., Fleury, A. ve Fleury M.T.T. eds, The Competitive Advantage of Emerging Market Multinationals, Cambridge University Press, Cambridge. pp.239 259.

Rugman, A. M.(2009). 'Theoretical Aspects of MNEs from Emerging Economies', Emerging Multinationals in Emerging Markets, ed. Ramamurti R. ve Singh J.V., Cambridge University Press, pp.42-63.

Rugman, A.M. \& Nguyen, Q.T.K. (2014). 'Modern international business theory and emerging economy MNCs', in Alvaro Cuervo-Cazurra and Ravi Ramamurti (eds), Understanding Multinationals from Emerging Markets, Cambridge University Press, pp 53-80.

Rugman, A. M., \& Verbeke, A. (1990). Global corporate strategy and trade policy. London: Croom Helm.

Port Finance International. (2012). 'Black Sea 2012 Special | Exclusive Interview with Robert Yuksel Yildirim'. April 25. Available at http://portfinanceinternational.com/features/item/ 157-pfi-black-sea-2012-special exclusive-interview-with-robert-yuksel-yildirim

Sewell, W. H. 1992 ‘A Theory of Structure: Duality, Agency and Transformation.' American Journal of Sociology 98: 1-29

Star Gazetesi. 2004. 'DuPont SA Sabancı'nın', October 9.

Today's Zaman, 2011. 'Godiva CEO says company needed a Turkish partner to grow', December 20.

UNCTAD. (2006). World investment report 2006: FDI from developing and transition economies: Implications for development. New York and Geneva: United Nations.

UNCTAD. (2015). World investment report 2015: Reforming International Investment Governance. New York and Geneva: United Nations. 
Williamson, P., Ramamurti, R., Fleury, A. ve Fleury M.T.T. (2013). The Competitive Advantage of Emerging Market Multinationals, Cambridge University Press, Cambridge.

Williamson P, Zeng M. (2009). 'Chinese multinationals: emerging through new Gateways'. In Emerging Multinationals in Emerging Markets, Ramamurti R, Singh JV (eds). Cambridge University Press: Cambridge, U.K.; 81-109. 